ated C.E., Ph.B., in 1859 , and a practical training during the same time in the workshops of his father's firm.

In I86I he entered the United States Navy, serving from $186 \mathrm{r}-186_{5}$ first as assistant engineer and then as engineer in charge of vessels; this period covered the great Civil War; and the unique experience which Thurston then enjoyed no doubt did much towards turning his mind to experimental research, and probably altered the whole course of his life's work.

In $x 865$ he was appointed assistant professor of natural philosophy in the United States Naval Academy at Annapolis, and as his chief died a few weeks afterwards, Thurston had entire charge of the department until he resigned the post, in 1871 , in order to take up the duties of professor of mechanical engineering in the Stevens Institute of Technology, an office he held until 1885 .

It was while he held this chair that Thurston began to make his name known, not only in America, but in Europe; he was a prolific writer on technical subjects, and did much valuable research work in connection with the U.S. Board appointed to deal with the subject of testing metals, notably in the investigation of the properties of the various alloys of copper, tin, and zinc. During this period he also visited Europe as the U.S. Commissioner to the Vienna Exposition of 1873 , and on his return published a valuable report.

In 1885 he took up the post which he held until his death, that of director of Sibley College; here he had full scope for his remarkable powers as a teacher and an organiser of scientific education of the most advanced character, and the most eloquent testimony to his success is the extraordinarily rapid growth in the number of students; from a mere handful in $188_{5}$, in eighteen years they have increased to nearly Iooo, and Sibley College to-day stands in the very front rank of the great technical colleges of the world devoted to the scientific training of the men who are to be the leaders of the engineering pro ession in all its branches. Much of its success is due to the fact that he was from the first able to win the sympathy and support of the leading engineers of the States, with the result that the Sibley College graduates never find the least difficulty in securing paid posts as soon as they finish their college training.

Thurston altogether wrote some 20 volumes and more than 300 separate scientific papers; his fertility with the pen, when one considers the labours he daily went through as a teacher and director, is amazing, and some of his books bear traces of the haste and pressure under which they were produced.

Of his books, the most noteworthy are the following:- "Friction and Lost Work," "The Materials of Engineering," "A Manual of the Steam Engine," "Steam Boiler Construction," and "A History of the Steam Engine" ; these are all in America recognised as standard works, and have found a ready sale also in this country. In fact, Thurston almost attained the same position as was held by Rankine for so many years in this country, and his books were consulted and used by thousands of young engineers scattered throughout the length and breadth of the great Republic.

Thurston was naturally the recipient of many honours; he was the first president of the American Society of Mechanical Engineers, holding office from I 880 to $\mathrm{I}_{88}$, vice-president of the American Association for the Advancement of Science in 1877,1878 , and I884, an LL.D. of the Brown University in 1889 , \&c. ; he was twice married, in 1865 to Susan Taylor Gladding (she died in 1878 ) and in 1880 to Leonora Boughton.

$$
\text { NO. I 779, VOL. 69] }
$$

Though Thurston devised several special forms of testing machines, he was not an inventive genius, and he did no work as a constructive engineer. It was as a writer and speaker that he made his influence felt, and how great that influence was will only be fully realised now that he has gone.

T. H. B

\section{SIR FREDERICK BRAMWELL, F.R.S.}

THE death of Sir Frederick Bramwell on Monday deprives engineering of one of its most energetic workers, and pure science of one who did much to promote its interests.

Sir Frederick Bramwell was born in London on March 7, 1818, and was apprenticed to one of the old school of mechanical engineers when he was sixteen years of age. After a varied experience he commenced practice on his own account as a civil engineer in 1853 , and the following year became a member of the Institution of Mechanical Engineers. $\mathrm{He}$ was elected an associate of the Institution of Civil Engineers in 1856 ; and in 1862 attained full membership.

In I874 Bramwell was chosen president of the Institution of Mechanical Engineers, and delivered an address in which he appealed to engineers to use to their utmost, and to use fairly, the natural resources at their command. As president of the Institution of Civil Engineers in 1884 , he described in his address the chief factors of past progress, and advocated the treatment of large stecl forgings by hydraulic pressure in place of steam hammers. He was president of the Mechanical Science Section of the British Association in 1872 , and again at Montreal in 1884 . He was elected president of the Association for the Bath meeting in 1888, when he delivered an address on the greatness of the works which the engineer creates out of minute beginnings.

Sir Frederick Bramwell received many marks of recognition from public bodies and learned societies. In I873 he was elected a Fellow of the Royal Society. In I $88 \mathrm{r}$, the Times relates, he was appointed nember of the Ordnance Committee, and in that capacity assisted in the framing of the rules under which iron and steel for the construction of large ordnance are tested before acceptance. After serving on the council and as a member of the board of management he was, on the retirement of Sir William Bowman in $188_{5}$, made honorary secretary of the Royal Institution. Always cordially lamenting the lack of facilities for technical education in his youth, he was a warm supporter of the movement for its advancement in this country. On the foundation of the City and Guilds of London Institute he was appointed by the Goldsmiths' Company one of its representatives on the governing body. A knighthood was conferred upon him in $\mathrm{I} 88 \mathrm{I}$, and a baronetcy in 1889 . He' received the honorary degree of D.C.L. from the Universities of Oxford and Durham, and that of LL.D. from Cambridge and McGill.

\section{NOTES.}

Prof. Ludwig Boltzmann has been elected honorary member of the Moscow Academy of Sciences.

THE deaths are announced of Prof. Heinrich Moehl director of the meteorological station at Cassel, at the age of seventy-one, and Dr. Nagel, formerly professor of geodesy in the technical high school at Dresden.

The next meeting of the American Association for the Advancement of Science, and affiliated societies, will be held at St. Louis during convocation week beginning on 